\title{
SEXUAL ACTIVITY, KNOWLEDGE AND THE USE OF CONTRACEPTION AMONG HIGH-SCHOOL STUDENTS IN NIŠ AND PREŠEVO
}

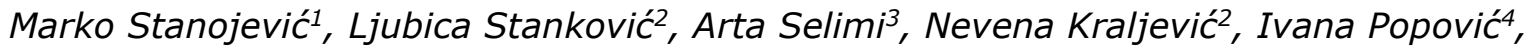 \\ Jasmina Popovićs
}

\begin{abstract}
Adolescents are tomorrow's adults and make up to $16 \%$ of the world's entire population. Caring about their reproductive health is both a mission and an obligation for all healthcare institutions and the community as a whole. The aim of this study was to examine sexual behavior, knowledge and the use of contraception, as well as the source of information on the topic, among high school students in Niš and Preševo.

An anonymous survey was conducted among 710 highschool stu-dents in Niš and 215 in Preševo in December 2017. It consisted of 13 questions about sexual activity, knowledge and the use of contraceptive methods.

The average age of the respondents was $17.2 \pm 0.5$ years. $31.5 \%$ of high school students from Niš had sexual intercourse, for the first time with $16.2 \pm 1.1$ years of age and 23.2 high school students from Preševo with $15.7 \pm 1.1$ years of age. Male students engaged significantly more often in sexual intercourse in comparison to their female counterparts. Students of both sexes and from both cities most frequently cited love as the reason for having sexual intercourse. The incidence of the regular use of contraception was statistically higher in Niš as opposed to Preševo ( $p=0.007)$ while being equal between the sexes $(p=0.738)$. The most used method of contraception during both first and last intercourse in both cities and both sexes was a condom. The majority of respondents from Niš $(83.5 \%)$ and Preševo $(93.2 \%)$ did not ask for professional advice. Female students asked for professional advice more often than male students. The Internet was the most frequent tool for gathering information about contraception in both cities (Niš 61.2\%, Preševo 55.0\%) and with both sexes (male $64.9 \%$, female $51.2 \%$ ). Two most common reasons for the use of contraception were protection from unwanted pregnancies (Niš 59.6\%, Preševo $71.2 \%$ ) and protection from sexually transmitted diseases (Niš 48.3\%, Preševo 16.6\%).

It is necessary to plan a long term strategy for sexual education with relevant information in both cities, in a manner appropriate for adolescents, while acknowledging the important role of the Internet in informing adolescent about this topic.
\end{abstract} Acta Medica Medianae 2019;58(3):40-48. health

Key words: high school students, sexual behavior, contraception, reproductive

\footnotetext{
${ }^{1}$ Clinical Center Niš, Clinic for Gynecology and Obstetrics, Niš, Serbia

2General Hospital "Dr Aleksa Savić", Prokuplje, Serbia

${ }^{3}$ Community health center Preševo, Preševo, Serbia

${ }^{4}$ University of Niš, Faculty of Medicine, medical student

${ }^{5}$ University of Niš, Faculty of Medicine, Department for

Gynecology and Obstetrics, Niš, Serbia
}

Contact: Marko Stanojević

Zetska 6/9, 18000 Niš, Serbia

E-mail: dr.stanojevic@yahoo.com

\section{Introduction}

Adolescents are the adults of tomorrow and they make up approximately $16 \%$ of the entire world 40 population, out of whom $85 \%$ live in developing countries. Adolescence is a sensitive period in one's development as it represents the transition from childhood to the state of physical, psychological and social maturity. One of the characteristics of modern society is the fact that adolescents start having sexual intercourse very early. More than a quarter of adolescent population from developing countries reported having started having sexual intercourse before the age of 15 (1).

Sexual and reproductive habits can have immediate, but also long-term consequences since they can lead to unwanted pregnancy and sexually transmitted diseases. According to the data issued by World Health Organization, while there is a steady decrease in early pregnancy rates (labour before the age of 15) in the world, the number of labours with older adolescents (labour before 18 years of age)stagnates. Every year, about 2 million girls who 
are not yet 15 get pregnant, while there are 21 million of those who get pregnant between 15 and 19 years of age. Within a group of 1000 adolescents, there are 22 of them who become mothers at that age in Serbia. Also, pregnancy and labour complications are considered to be the leading causes of death among girls between 15 and 19 years of age in the world (2).

Sexually transmitted diseases, first of all, AIDS, are the leading cause of death among adolescents in Africa and the second most important in the world. AIDS-related deaths have tripled among adolescents in comparison to the rates of 2000, while their number tends to decline within grownups. Twenty-six adolescents between 15 and 19 years of age get infected with AIDS every hour in the world (220.000 in total), according to the data from 2014 (3). In addition to that, sexually transmitted diseases, especially those caused by Chlamydia trachomatis, Trichomonas vaginalis, HSV, HPV, and Naisseria gonorrhoeaeare more common among adolescents (4).

Reproductive health represents a key element for a healthy life. Numerous factors, such as socioeconomic status, demographic, cultural, religious and individual characteristics of a society and an individual are closely intertwined and influence one's awareness of reproductive health. Taking into consideration that young people are susceptible to different influences coming from the immediate and wider social environment, with the influences affecting their knowledge, attitudes, and behaviour related to sexuality and reproduction to a smaller or larger extent, reproductive healthcare is the job and responsibility of health institutions and the whole society. Education concerning the importance of the use of contraceptives is important in protection against sexually transmitted diseasesas, as well as in the prevention of mortality and morbidity of fertile women caused by abortive procedures (5), especially because the percentage of young people (between the ages of 15 and 19) who use contraceptives is just $21-64 \%$ in the world.

\section{The aim of the study}

The reasearch has been conducted to examine sexual behaviour, knowledge about and the use of contraceptives among high school students in Niš and Presevo and, also, to serve as a source of information about this topic.

\section{Materials and methods}

An anonymous survey was conducted on 215 high school third-grade students from Niš and 215 students from Preševo in December 2017. The survey included 13 questions about sexual activity, the knowledge of the use of contraceptive methods and the source of information regarding this topic.

The data are shown in the form of the arithmetic mean and standard deviation, that is in the form of absolute and relative values. On condition that there is normal distribution of data, continually recorded marks were compared using the t-test for independent samples. If there was no normal distribution, continuous marks were compared with the Mann-Whitney test. Attributive marks between two groups were compared using the chi-squared test or Fisher's exact test (if the absolute frequency was less than 5). The hypothesis was tested with the materiality threshold of $p<0,05$. Data analysis was done within SPSS 16.0.

\section{Results}

The total number of respondents was 710 and those were third-grade high school students from Niš, out of whom 319 female high school students, 119 female secondary vocational school students, 208 male high school students and 64 male secondary vocational school students. The survey was conducted on 215 students from Preševo, 103 of whom were girls attending high schools, 19 girls from secondary vocational schools, 67 boys from high schools and 26 boys from secondary vocational schools. There were 36 invalid questionnaires, that is, those that were filled in incorrectly $(3.89 \%)$.

The average age of the respondents is $17.2 \pm$ 0.5 years.

As far as Niš is concerned, 79 (46.2\%) students from vocational schools engaged in sexual intercourse (of whom 38 (67.9\%) male and 41 (35.7\%) female students), as well as 133 (26.4\%) students from high schools (74 (38.3\%) of whom male and 53 (19\%) female students). Statistics showed that students from vocational schools engaged in sexual intercourse more often than students from high schools ( $p<0.001$ ). The number of male students who engaged in sexual intercourse was $112(45.0 \%)$, while there were 100 female respondents $(23.5 \%)$ (Table 1$)$. Also, the statistics showed that male students engaged themselves in sexual intercourse more often than female students from schools in Niš ( $p<0.001)$.

As far as Preševo is concerned, 24 (53.3\%) students from vocational school engaged in sexual intercourse $(23(88.5 \%)$ of whom were male and 1 (5.3\%) female students), as well as $49(28.8 \%)$ students from high school (46 of whom $(68.7 \%$ ) were male and 3 female (2.9\%) students). The statistics showed that students from vocational school engaged more often in sexual intercourse in comparison to students from high school $(p=0.004)$. The number of sexually active students was 73, with 69 (74.2\%) male students and 4 (3.3\%) female students (Table 1). Regarding the schools from Preševo, the statistics showed that, when compared to female students, male students engaged more often in sexual intercourse $(p<0.001)$.

A total of 212 (31.5\%) high school students of both sex from Niš and a total of 43 (23.2\%) high school students of both sex from Preševo had sexual intercourse (Graph 1). According to the statistics, the students from Niš engaged in sexual intercourse more often than the students from Preševo ( $p=$ 0.038). 
The average age when an adolescent from Niš had his first sexual intercourse was $16.2 \pm 1.1$ years, and for Preševo that was $15.7 \pm 1.1$ years. Fe-male students started having sexual intercourse at the age of $16.5 \pm 0.90$ on average, while male stu-dents had it at the age of $15.7 \pm 1.2$. The age when they had first sexual intercourse was similar if the criterion for the comparison was the gender ( $p=$ $0.137)$, that is the city ( $p=0.156)$.

The number of sexual partners of the students from Niš is significantly smaller in comparison to the students from Preševo ( $2 \pm 1.4$ vs. $4.0 \pm 3.0$, $\mathrm{p}<0.001)$. Male students had more partners compared to female students $(2.8 \pm 2.2$ vs. $1.5 \pm 0.9, p$ $<0.001$ ).

Table 1. Engagement in sexual intercourse in schools that were involved in the survey

\begin{tabular}{|c|c|c|c|c|c|c|c|c|}
\hline \multirow{3}{*}{ Answer } & \multicolumn{4}{|c|}{ Niš } & \multicolumn{4}{|c|}{ Preševo } \\
\hline & \multicolumn{2}{|c|}{ Vocational schools } & \multicolumn{2}{|c|}{ High schools } & \multicolumn{2}{|c|}{ Vocational schools } & \multicolumn{2}{|c|}{ High schools } \\
\hline & Male & Female & Male & Female & Male & Female & Male & Female \\
\hline Yes & $\begin{array}{c}38 \\
(67.9 \%) \\
18 \\
(32.1 \%)\end{array}$ & $\begin{array}{c}41 \\
(35.7 \%) \\
74 \\
(64.3 \%)\end{array}$ & $\begin{array}{c}74 \\
(38.3 \%) \\
119 \\
(61.7 \%) \\
\end{array}$ & $\begin{array}{c}59 \\
(19.0 \%) \\
251 \\
(81.0 \%) \\
\end{array}$ & $\begin{array}{c}23 \\
(88.5 \%) \\
3 \\
(11.5 \%)\end{array}$ & $\begin{array}{c}1 \\
(5.3 \%) \\
18 \\
(94.7 \%) \\
\end{array}$ & $\begin{array}{c}46 \\
(68.7 \%) \\
21 \\
(31.3 \%) \\
\end{array}$ & $\begin{array}{c}3 \\
(2.9 \%) \\
100 \\
(97.1 \%)\end{array}$ \\
\hline
\end{tabular}

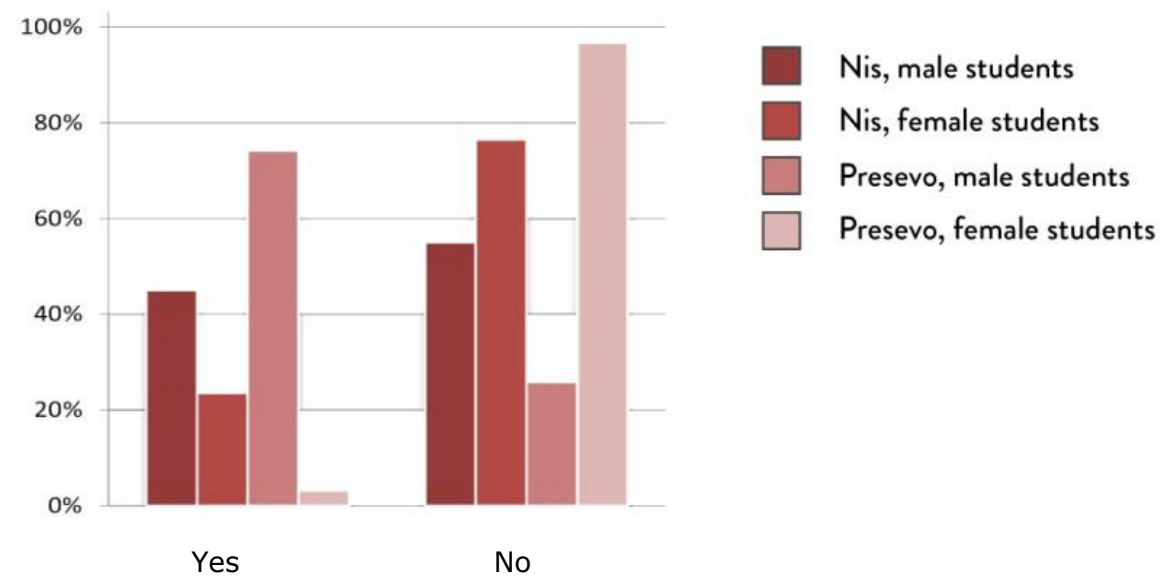

Graph 1. Percentage of students engaged in sexual intercourse

The students of both cities mentioned the love for their partner as the most common reason for engaging in sexual intercourse (Niš - 38.5\%, Preševo - 39.4\%). The most common reason for engaging in sexual intercourse regarding the gender of the respondents is love for their partner: male students - 33.5\%, female students - $45.7 \%$ (Table 2 ). In comparison to other reasons for engaging in sexual intercourse, students mentioned love more often $(p=0.020)$.

Contraceptive methods were used occasionally or always by 68 ( $86.1 \%)$ students of secondary vocational schools and $113(84.3 \%)$ students of high schools in Niš. Contraceptive methods were used occasionally or always by $97(86.6 \%)$ male and $84(83.2 \%)$ female students (Table 3$)$. No statistically relevant difference was found in terms of the use of contraceptive methods either occasionally or always between vocational schools and high schools ( $p=0.922$ ) nor regarding the gender of the repondents $(p=0.610)$.

As far as Preševo is concerned, 24 (87.5\%) students from secondary vocational schools and 33 $(67.3 \%)$ high school students used contraceptive methods occasionally or always (Table 3). It was determined that constant use of contraception and their occasional use were similar in the schools that were surveyed in Preševo ( $p=0.119)$.

The frequency of regular use of contraception is statistically more frequent in Niš than in Preševo $(p=0.007)$. The use of contraception is similar with reference to the gender ( $p=0.738)$ (Graph 2$)$.

The most common type of contraception during the first sexual encounter in both cities is a condom: Niš - 180 students (73.8\%), Preševo - 61 students $(83.6 \%)$. The most common type of contra- 
ception during their last sexual encounters in both cities was a condom (Niš - 142 students (64.0\%), Preševo - 53 students (72.6\%)). Judging from the above-mentioned data, the tendency of decrease in contraception after the first encounter is visible. A condom was the most common contraceptive method during the first sexual intercourse with both males and females: males - $163(81.5 \%)$ and females -
$78(66.7 \%)$. Also, the condom was the most common method of contraception during their last sexual intercourse for both genders: males - 127 $(70.2 \%)$ and females - 68 (59.6\%). Statistics has shown that male students use a condom more frequently ( $p=0.004$ ) than female during their first sexual inter-course (Graph 3).

Table 2. The reason for the first sexual relationship

\begin{tabular}{|c|c|c|c|c|c|c|c|c|c|c|c|c|c|c|c|c|}
\hline \multirow{4}{*}{ Answer } & \multicolumn{8}{|c|}{ Niš } & \multicolumn{8}{|c|}{ Preševo } \\
\hline & \multicolumn{4}{|c|}{ "Vocational school } & \multicolumn{4}{|c|}{ "High school } & \multicolumn{4}{|c|}{ Vocational school } & \multicolumn{4}{|c|}{ "High school } \\
\hline & \multicolumn{2}{|c|}{$\mathrm{M}$} & \multicolumn{2}{|c|}{$\mathrm{F}$} & \multicolumn{2}{|c|}{ M } & \multicolumn{2}{|c|}{$\mathrm{F}$} & \multicolumn{2}{|c|}{$\mathrm{M}$} & \multicolumn{2}{|c|}{$\mathrm{F}$} & \multicolumn{2}{|c|}{$M$} & \multicolumn{2}{|c|}{$\mathrm{F}$} \\
\hline & $\mathrm{N}$ & $\%$ & $\mathrm{~N}$ & $\%$ & $\mathrm{~N}$ & $\%$ & $\mathrm{~N}$ & $\%$ & $\mathrm{~N}$ & $\%$ & $\mathrm{~N}$ & $\%$ & $\mathrm{~N}$ & $\%$ & $\mathrm{~N}$ & $\%$ \\
\hline Love & 19 & 47.4 & 32 & 78.0 & 31 & 41.9 & 39 & 66.1 & 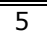 & 21.7 & 1 & 100 & 19 & 41.3 & 3 & 100 \\
\hline Opportunity & 9 & 31.6 & 4 & 9.8 & 30 & 40.5 & 12 & 20.3 & 0 & 0.0 & 0 & 0.0 & 9 & 19.6 & 0 & 0.0 \\
\hline Curiosity & 9 & 15.8 & 8 & 19.5 & 18 & 24.3 & 11 & 18.6 & 11 & 47.8 & 0 & 0.0 & 9 & 19.6 & 0 & 0.0 \\
\hline $\begin{array}{l}\text { Influence of } \\
\text { alcohol or } \\
\text { drugs }\end{array}$ & 3 & 10.5 & 3 & 7.3 & 8 & 10.8 & 4 & 6.8 & 1 & 4.3 & 0 & 0.0 & 3 & 6.5 & 0 & 0.0 \\
\hline Readiness & 1 & 10.5 & 14 & 34.1 & 20 & 27.0 & 25 & 42.4 & 5 & 21.7 & 0 & 0.0 & 1 & 2.2 & 0 & 0.0 \\
\hline Coercion & 0 & 7.9 & 4 & 9.8 & 1 & 1.4 & 1 & 1.7 & 0 & 0.0 & 0 & 0.0 & 0 & 0.0 & 0 & 0.0 \\
\hline Other & 3 & 0.0 & 0 & 0.0 & 2 & 2.7 & 3 & 5.1 & 1 & 4.3 & 0 & 0.0 & 3 & 6.5 & 0 & 0.0 \\
\hline
\end{tabular}

Table 3. The use of contraceptive methods

\begin{tabular}{|c|c|c|c|c|c|c|c|c|}
\hline \multirow{3}{*}{ Answer } & \multicolumn{4}{|c|}{ Niš } & \multicolumn{4}{|c|}{ Preševo } \\
\hline & \multicolumn{2}{|c|}{ Vocational schools } & \multicolumn{2}{|c|}{ High schools } & \multicolumn{2}{|c|}{ Vocational schools } & \multicolumn{2}{|c|}{ High schools } \\
\hline & Male & Female & Male & Female & Male & Female & Male & Female \\
\hline $\begin{array}{c}\text { Yes, always } \\
\text { Yes, } \\
\text { occasionally }\end{array}$ & $\begin{array}{c}18 \\
(47.4 \%) \\
17 \\
(44.7 \%)\end{array}$ & $\begin{array}{c}21 \\
(51.2 \%) \\
12 \\
(29.3 \%) \\
8\end{array}$ & $\begin{array}{c}35 \\
(47.3 \%) \\
27 \\
(36.5 \%) \\
12\end{array}$ & $\begin{array}{c}35 \\
(59.3 \%) \\
16 \\
(27.1 \%) \\
9\end{array}$ & $\begin{array}{c}9 \\
(39.1 \%) \\
11 \\
(47.8 \%) \\
3\end{array}$ & $\begin{array}{c}0 \\
1 \\
(100 \%)\end{array}$ & $\begin{array}{c}14 \\
(30.4 \%) \\
17 \\
(37.0 \%) \\
15\end{array}$ & $\begin{array}{c}1 \\
(33.3 \%) \\
1 \\
(33.3 \%) \\
1\end{array}$ \\
\hline No & $3(7.9 \%)$ & (19.5\%) & $(16.2 \%)$ & $(15.3 \%)$ & $(13.0 \%)$ & 0 & $(32.6 \%)$ & $(33.3 \%)$ \\
\hline
\end{tabular}

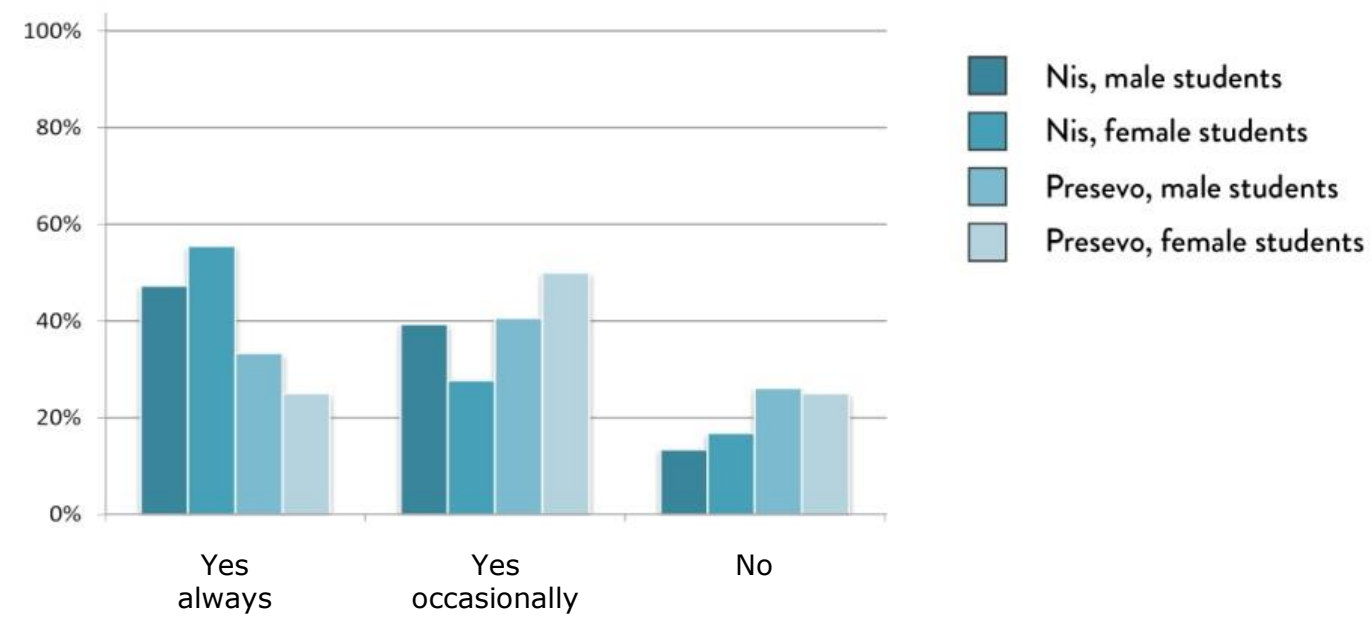

Graph 2. Frequency of contraception use 


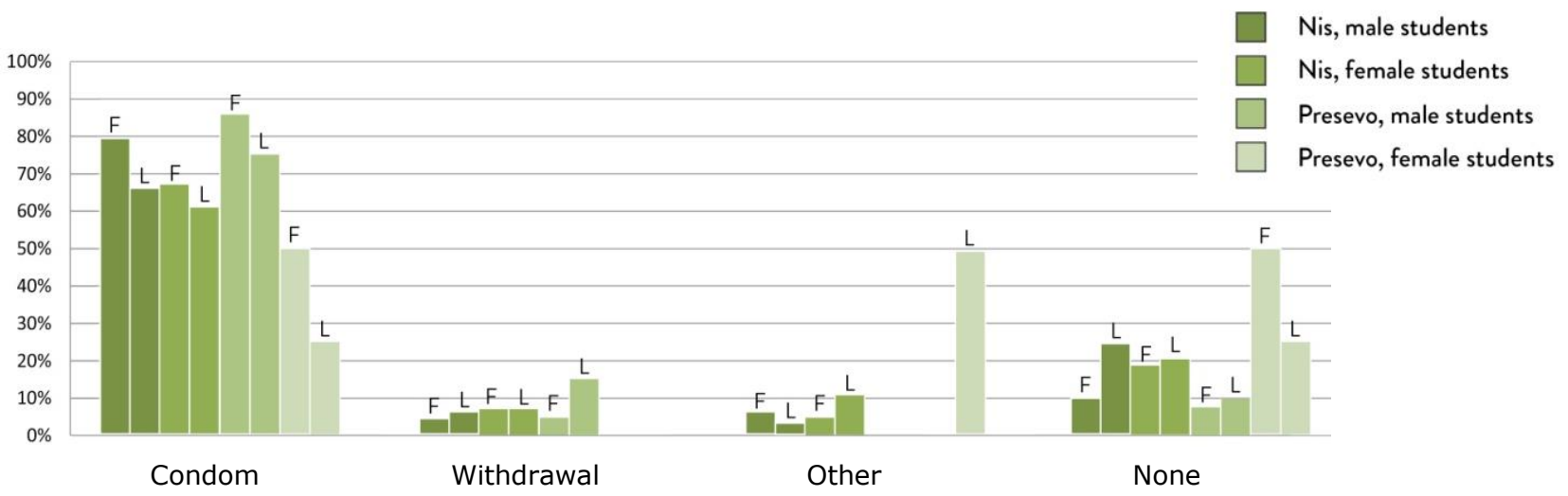

Graph 3. Methods of contraception used during the first and the last sexual intercourse

As many as 177 (83.5\%) students from Niš and $68(93.2 \%)$ students from Preševo did not seek professional advice on contraception. The Preševo students sought expert advice on contraception less frequently in comparison to the students from Niš ( $p$ $=0.040)$. Also, $165(91.2 \%)$ male and $80(76.9 \%)$ female students did not ask for professional help on contraception. Statistics have shown that female students were more likely $(p=0.002)$ to seek professional advice on contraception (Graph 4).

The most common source of information on contraception was the Internet in both cities: Niš -
$61.2 \%$, Preševo $-55.0 \%$, as with the gender: males - $64.9 \%$, females - $51.2 \%$ were in favour of the Internet (Graph 5).

Two most common reasons for the use of contraception were protection against unwanted pregnancy (Niš - 59.6\%, Preševo - 71.2\%) and protection against sexually transmitted diseases (Niš $48.3 \%$, Preševo - $31.5 \%$ ), so $60.5 \%$ of male and $70.6 \%$ of female students considered these reasons to be crucial for the use of contraception (Table 4).

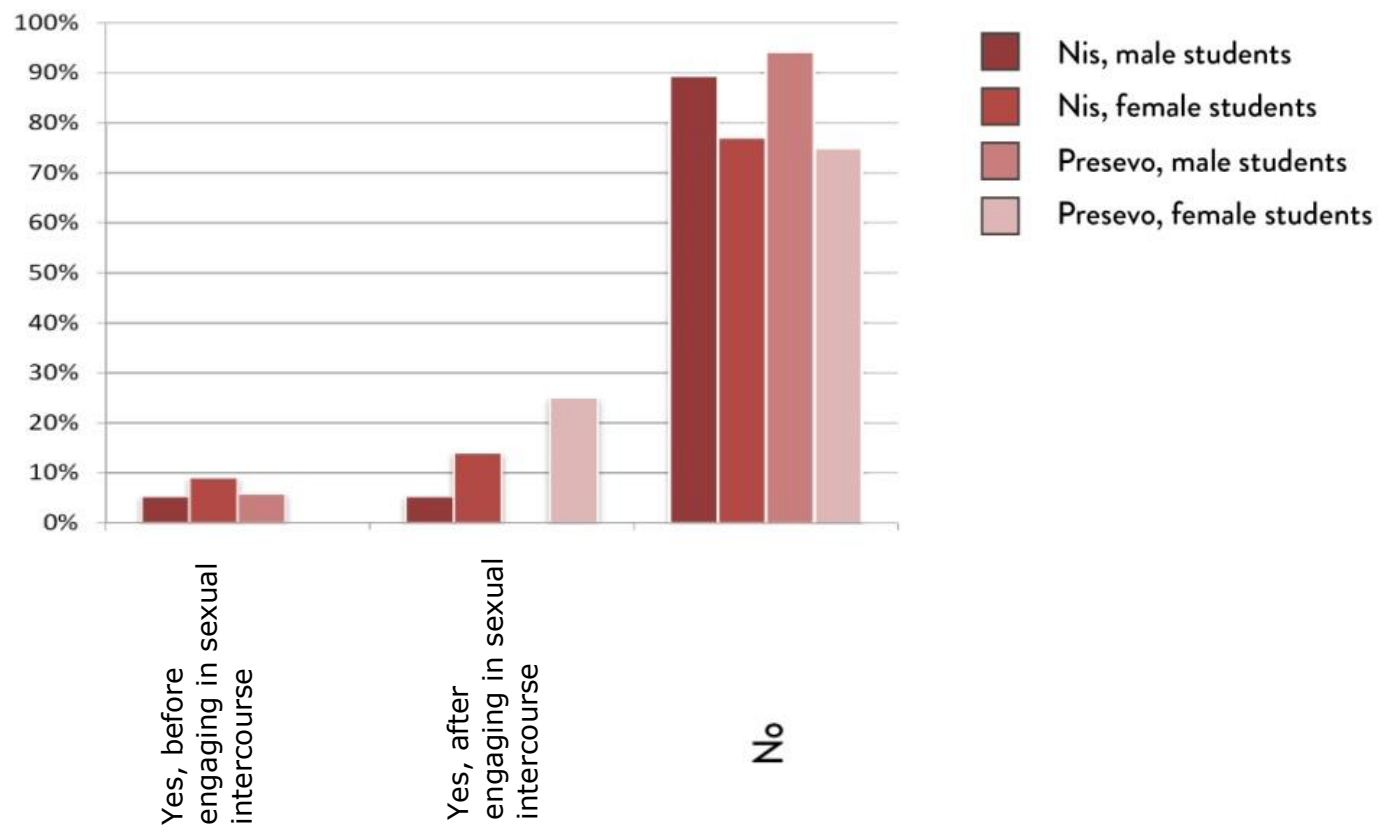

Graph 4. Consulting a healthcare professional about the use of contraception 


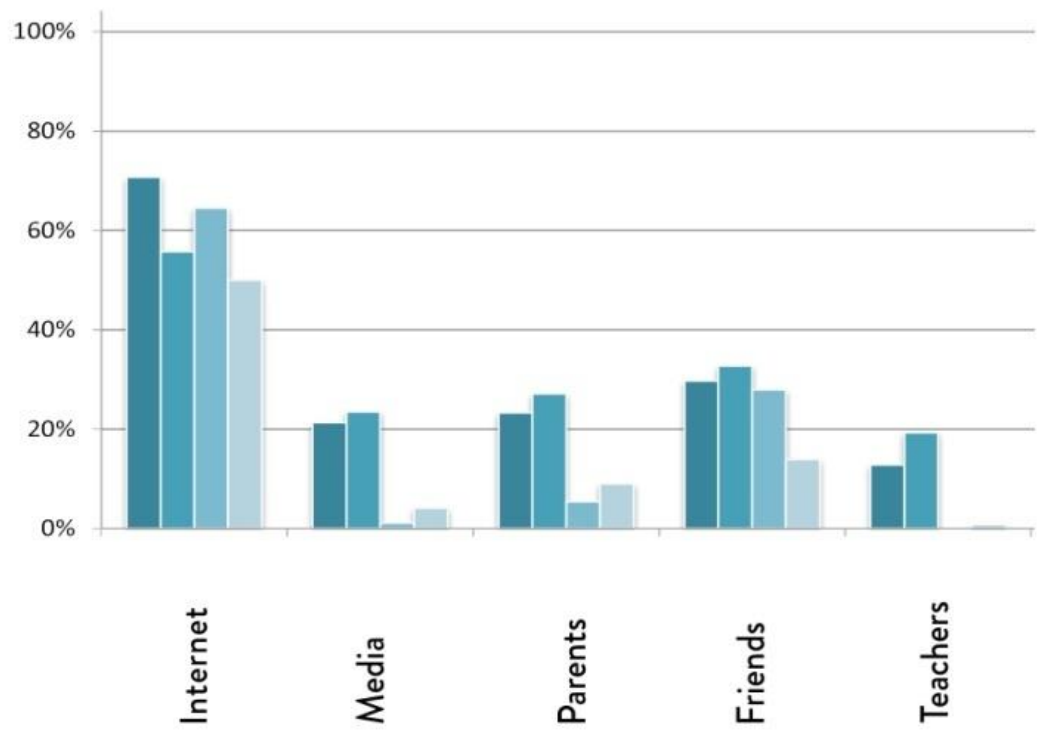

Nis, male students

Nis, female students

Presevo, male students

Presevo, female students

Graph 5. Ways of informing about contraception

Table 4. Reason for the use of contraception

\begin{tabular}{|c|c|c|c|c|c|c|c|c|}
\hline \multirow{3}{*}{ Answer } & \multicolumn{4}{|c|}{ Niš } & \multicolumn{4}{|c|}{ Preševo } \\
\hline & \multicolumn{2}{|c|}{ Vocational schools } & \multicolumn{2}{|c|}{ High schools } & \multicolumn{2}{|c|}{$\begin{array}{c}\text { Vocational } \\
\text { schools }\end{array}$} & \multicolumn{2}{|c|}{ High schools } \\
\hline & Male & Female & Male & Female & Male & Female & Male & Female \\
\hline $\begin{array}{l}\text { Protection } \\
\text { against } \\
\text { unwanted } \\
\text { pregnancy }\end{array}$ & $\begin{array}{c}27 \\
(48.2 \%)\end{array}$ & $\begin{array}{c}32 \\
(27.8 \%)\end{array}$ & $\begin{array}{c}55 \\
(74.3 \%)\end{array}$ & $\begin{array}{c}52 \\
(88.1 \%)\end{array}$ & $\begin{array}{c}15 \\
(57.7 \%)\end{array}$ & $\begin{array}{c}1 \\
(100 \%)\end{array}$ & $\begin{array}{c}26 \\
(61.9 \%)\end{array}$ & $\begin{array}{c}2 \\
(66.7 \%)\end{array}$ \\
\hline $\begin{array}{l}\text { Protection } \\
\text { against STD }\end{array}$ & $\begin{array}{c}22 \\
(39.3 \%)\end{array}$ & $\begin{array}{c}22 \\
(19.1 \%)\end{array}$ & $\begin{array}{c}52 \\
(70.3 \%)\end{array}$ & $\begin{array}{c}38 \\
(64.4 \%)\end{array}$ & $\begin{array}{c}8 \\
(30.8 \%)\end{array}$ & 0 & $\begin{array}{c}15 \\
(35.7 \%)\end{array}$ & 0 \\
\hline $\begin{array}{l}\text { Regulation of } \\
\text { menstrual } \\
\text { cycle }\end{array}$ & 0 & 0 & 0 & $\begin{array}{c}1 \\
(1.7 \%)\end{array}$ & 0 & 0 & 0 & 0 \\
\hline $\begin{array}{l}\text { Within other } \\
\text { therapy }\end{array}$ & 0 & 0 & 0 & 0 & 0 & 0 & $\begin{array}{c}1 \\
(2.4 \%)\end{array}$ & 0 \\
\hline
\end{tabular}

\section{Discussion}

Modern societies consider one of their priorities to preserve the reproductive health of the adolescent population. For this reason, we find a significant number of studies dealing with the testing of knowledge and use of contraceptive devices among adolescents.

According to the data obtained in our research, $31.5 \%$ of high school students from Niš ( $45.0 \%$ of male and $23.5 \%$ of female students) had their first sexual intercourse at the age of $16.2 \pm 1.1$ years and $23.2 \%$ of high school students from Preševo ( $74.2 \%$ of male and $3.3 \%$ of female students) had their first sexual intercourse at the age of 15.7 \pm 1.1 years. Similar studies were conducted on the territory of the Republic of Serbia, countries of the region and the world. According to the research of the Institute of Public Health of Serbia from 2013, $33.1 \%$ of young people in Serbia between the age of 15 and 19 engaged in sexual intercourse (6). A survey conducted in Indjija in 2015, which included a group of 490 adolescents aged 15-19, (did not show a significant deviation from the results obtained by our survey) of the total number of adolescents that were questioned, $31.22 \%$ adolescents had sexual intercourse, of whom $39.57 \%$ of boys and $19.80 \%$ of girls. The median of the age of the first sexual inter-course for adolescents questioned is 16.33 years, 16.25 years for boys and 16.53 years for girls (7). Data obtained by interviewing high school students in Zaječar in 2012 show that $21.3 \%$ of the students had sexual intercourse, with $45.1 \%$ of the boys interviewed to have sexual experience and only $10.2 \%$ of the girls. The average age of the first sexual intercourse was 16.3 years for girls and 15.5 
years for boys (8). According to the studies conducted in 4 large cities in Croatia (Zagreb, Split, Rijeka and Osijek), 39.4\% of adolescents had sexual intercourse ( $51 \%$ of boys and $27 \%$ of girls), girls at the age of 16 , and boys at the age of 15 (9). According to the research conducted in the Tuzla Canton, $13.18 \%$ of adolescents were sexually active. The average age to have sex for the first time was 16.5 years for girls and 15.7 years for boys (10). A survey conducted among adolescents in Slovenia showed that $53 \%$ of high school students had sexual intercourse, with no statistical significance with reference to the gender as well as to the age they were when they had their first sexual intercourse (11). According to the data obtained through an extensive research of high-risk behaviour among highschool students from 43 federal states in the US, $43.7 \%$ of the respondents had sexual relations (12). A study carried out in Sweden in 2014 showed that $21.8 \%$ of fifteen-year-old high school students reported having sexual intercourse. Male-female ratio was 3:1, while the average age at which to have first sexual relation was $14.5 \pm 0.9$ (13). According to the statistics, male students were more likely to have intercourse earlier and more often than female students. According to the available information, the age of the first sexual intercourse does not differ significantly from other cities that were compared in Serbia, countries from the region and the world.

The frequency of regular use of contraceptive methods is statistically more frequent in Niš than in Preševo and it is gender-balanced. The most common method of contraception during the first and last relationship in both cities and for both sexes is a condom, with a reduction in the use of contraception after the first intercourse. The percentage of the use of oral contraceptives, as well as of the double method, is low ( $7 \%$ in Niš, $0 \%$ in Preševo). Unlike the results of the research conducted for the purposes of this paper, according to the data from the research Sedlecki et al. 2001, female adolescents in Belgrade most often rely on the coitus interuptus method $(54.3 \%)$. Results similar to ours were obtained in the above-mentioned research in Indjija (7) and Zaječar (8). The study carried out in Slovenia also shows a reduced use of a condom after the first sexual encounter (from 75 to $50 \%$ ). However, there is a trend of an increase in the use of oral contraceptives (from 7 to $32 \%$ ), which is not the case in our research (11). US data show that oral contraceptives are used more frequently (45\%) than condoms (38\%) among adolescents (14).

Most developed countries, such as Sweden, have health centers where young people can receive adequate information about sexuality, interpersonal relationships, contraception and sexually transmitted diseases (15). However, this type of expert help is not used by the majority of respondents in Serbia, those from Niš $(83.5 \%)$ and Preševo (93.2\%). Instead of professionals, the Internet is the most common source of information about contraception in both cities (Niš $61.2 \%$, Preševo $55.0 \%$ ) and with both genders (male $64.9 \%$, female $51.2 \%$ ). The Internet is a creation of civilisation, without which everyday life cannot be imagined in developed countries, especially among the younger population.
However, it is also an inexhaustible source of falsehoods and half-truths that carry an enormous risk for both, the physical and psychological state of each individual. The young are particularly sensitive as they are quite susceptible to accept unverified and inaccurate information. Consequently, they are not aware of the risks of sexual activity and disregard the importance of contraceptive method use. On the other hand, if properly used, the Internet can be a powerful tool for learning, creating awareness and a model of behavior. For this reason, the huge potential that the Internet has in providing professional and clear information cannot be ignored, taking into account that in this way one can quickly and easily overcome the barrier of fear, shame, and prejudice that potentially exists when addressing parents or teachers on the subject. Additionally, the fact is that the percentage of the students interviewed who sought information and advice on contraception from parents or teachers is lower than the percentage of respondents who asked their peers for information. Moreover, in comparison to Niš, a fairly smaller number of adolescents in Presevo asked the closest authorities for advice (parents 9\%, teachers $1 \%$ in Preševo, parents $27 \%$, teachers $19 \%$ in Niš). Such results may be explained by cultural and religious characteristics.

The data obtained point to the need for the education system to take more part in health and reproductive education of young people. The education system of a large number of countries in Europe and the USA includes some form of sexual education for schoolchildren, which gives concrete and measurable results in the form of the reduced number of unwanted pregnancies, abortions, sexually transmitted diseases and complications that are included in these conditions (16).

The results of the research that was conducted pointed to a worryingly small degree of participation of the health system in informing young people and promoting reproductive health. The health system can help young people overcome the shame and mistrust that could be the reason for such results by means of the implementation of adolescent sexual education through specifically organized counseling. Such counseling should allow adolescents to develop trust in their doctors and build a friendly relationship so as to get the most accurate information about sexuality, contraception, and diseases that are transmitted through sexual contact.

\section{Conclusion}

The age of the first sexual intercourse, as well as the percentage of sexually active adolescents included in our research, does not deviate significantly from other parts of Europe. However, the reduction in condom use after the first intercourse has not been replaced by the use of other contraceptive devices, as is the case in some Western European countries.

The results of the research have shown that adolescents receive most information on this topic from the Internet, then from their peers, and, to a considerably smaller extent, from their parents, 
teachers and healthcare workers. However, the information obtained by means of the Internet or from peers may be false, and cannot always be considered relevant and may also threaten their health. This leads us to conclude that there is no need to ignore the great potential of the Internet; instead, we should use it to spread relevant information in a way that is acceptable to adolescents. The use of the Internet reagarding adolescent education on reproductive health should be incorporated into health and education systems, thus making the information that the adolescents receive via the Internet more accurate.
Sexual education inside and outside the school education system, the health system, as well as the increase in the availability of contraceptive devices to adolescents should become integral parts of the strategy for improving the reproductive health of adolescents. The work of the health and education system in the field of reproductive health should essentially be brought closer to the way of thinking of adolescents and the information should be provided in a comprehensible and interesting way, especially through health education lessons in schools and workshops within youth counseling centers at community health centers.

\section{References}

1. Rodgers A, Radulović O, Babić S, Veljković M, Stefanović A, Šagrić Č, Bulatović K. Reproductive Health of Youth in the World and Serbia. Acta Fac Med Naiss 2014; 31(4):219-24.

2. WHO. Adolescent Sexual and Reproductive Health. "Cited 2018 Jan". Available from: URL: http://www.who.int/reproductivehealth/topics/adolesc ence/en/

3. UNICEF. Adolescents. "Cited 2018 Feb". Available from: URL: https://data.unicef.org/topic/adolescents/

4. Greydanus DE, McAnarney ER. Menstruation Disorders in Adolescence. Curr Probl Pediatr 1982; 12(10):161.[PubMed][CrossRef]

5. Sedlecki K. Ponašanje i stavovi adolescenata relevantni za reproduktivno zdravlje. Stanovništvo 2001; 39 (1-4):91-117.

6. Institut za javno zdravlje Srbije. Rezultati istraživanja zdravlja stanovništva Srbije 2013; 54-6.

7. Rožek Mitrović $T$, Petrović $V$, Višnjevac D. Sexual Behavior and Impact on the Reproductive Health of Adolescents in the Municipality of Indjija. Journal of the Association of Preventive Pediatrics of Serbia 2017; 3(1-2).

8. Savić Mitić $\breve{Z}$, Trailović M, Mitić D. Knowledge and Application of the Methods of Contraception among the Adolescents of the High-school Students' Home in Zaječar. Timočki medicinski glasnik 2012; 37(3):13944.
9. Dabo J, Malatesnić Đ, Janković S, Bolf Malović M, Kosanović V. Zaštita reproduktivnog zdravlja mladih modeli prevencije. Medicina 2008; 44:72-9.

10. Hadžimehmedović A, Balić A, Balić D. Poznavanje i primena metoda kontracepcije kod srednjoškolaca tuzlanskog kantona. Medicinski glasnik 2006; 3:53-7.

11. Pinter B, Verdenik I, Grebenc M, Ceh F. Sexual Activity and Contraceptive Use Among Secondary-school Students in Slovenia. Eur J Contracept Reprod Health Care 2009; 14(2):127-33.[PubMed][CrossRef]

12. Eaton DK, Kann L, Kinchen S,Shanklin S, Flint $\mathrm{KH}$, Hawkins J,et al. Centers for Disease Control and Prevention (CDC). Youth Risk Behavior Surveillance United States, 2011. MMWR Surveill Summ 2012; 61(4): 1-162.[PubMed]

13. Makenzius M, Larsson M. Early Onset of Sexual Intercourse is an Indicator for Hazardous Lifestyle and Problematic Life Situation. Scand J Caring Sci 2013; 27(1):20-6. [PubMed][CrossRef]

14. Polaneczky M. Adolescent Contraception. Curr Opin Obstet Gynecol 1998; 10(3):213-9.[CrossRef]

15. Persson E. The Sexual Behavior of Young People. Br J Obstet Gynaecol 1993; 100(12):1074-6. [PubMed][CrossRef]

16. Leven S. Protecting the University's student body. The Cavalier Daily 2005 "Cited 2005 May". Available from: URL:http://www.cavalierdaily.com/article/2005/04/pr otecting-the-universitys-student-body 


\title{
SEKSUALNA AKTIVNOST, UPOTREBA I POZNAVANJE METODA KONTRACEPCIJE MEĐU SREDNJOŠKOLCIMA NIŠA I PREŠEVA
}

\author{
Marko Stanojević ${ }^{1}$, Ljubica Stanković2 ${ }^{2}$ Arta Selimi ${ }^{3}$, Nevena Kraljević2 ${ }^{2}$ Ivana Popović4, \\ Jasmina Popovićs
}

\author{
${ }^{1}$ Klinika za ginekologiju i akušerstvo, Klinički centar Niš, Niš, Srbija \\ Opšta bolnica "dr Aleksa Savić" Prokuplje, Prokuplje, Srbija \\ ${ }^{3}$ Dom zdravlja Preševo, Preševo, Srbija \\ ${ }^{4}$ Univerzitet u Nišu, Medicinski fakultet, Niš, Srbija \\ Unniverzitet u Nišu, Medicinski fakultet, Katedra za ginekologiju i akušerstvo, Niš, Srbija
}

Kontakt: Marko Stanojević

Zetska 6/9, 18000 Niš, Serbia

E-mail: dr.stanojevic@yahoo.com

Adolescenti su sutrašnji odrasli i čine približno $16 \%$ celokupnog svetskog stanovništva. Briga o njihovom reproduktivnom zdravlju zadatak je i obaveza zdravstvenih institucija i društvene zajednice.

Istraživanje je sprovedeno u cilju ispitivanja seksualnog ponašanja, poznavanja i primene kontracepcije među srednjoškolcima Niša i Preševa, kao i izvora informacija o ovoj temi.

Anonimna anketa sprovedena je decembra 2017 godine kod 710 srednjoškolaca Niša i 215 srednjoškolaca Preševa. Anketa je sadržala 13 pitanja o seksualnoj aktivnosti, poznavanju i korišćenju kontraceptivnih metoda, kao i o izvoru informacija o ovoj temi.

Prosek godina života anketiranih je 17,2 godine $\pm 0,5$ godina. $U$ seksualne odnose stupilo je $31,5 \%$ srednjoškolaca iz Niša, prvi put sa 16,2 godine $\pm 1,1$ godina i $23,2 \%$ srednjoškolaca iz Preševa, prvi put sa 15,7 godina $\pm 1,1$ godina. Učenici su statistički značajno češće i ranije stupali u seksualne odnose u odnosu na učenice. Kao najčešći razlog stupanja u seksualne odnose srednjoškolci oba grada i oba pola naveli su ljubav prema partneru. Učestalost redovnog korišćenja metoda kontracepcije statistički je češća u Nišu u odnosu na Preševo ( $p$ $=0,007)$, a ujednačena prema polu $(p=0,738)$. Najčešći vid kontracepcije tokom prvog $\mathrm{i}$ poslednjeg odnosa u oba grada i kod oba pola je kondom. Najveći broj anketiranih, iz Niša $(83,5 \%)$ i Preševa $(93,2 \%)$, nije tražilo stručnu pomoć o kontracepciji. Učenice su češće tražile stručnu pomoć. Internet je najčešći vid infor-misanja o kontracepciji u oba grada (Niš 61,2\%; Preševo 55,0\%) i kod oba pola (muški 64,9\%; ženski 51,2\%). Dva najčešća razloga za primenu kontracepcije su zaštita od neželjene trudnoće (Niš 59,6\%; Preševo $71,2 \%$ ) i zaštita od polno prenosivih bolesti (Niš 48,3\%; Preševo 31,5\%).

$\cup$ oba grada potrebno je dugoročno planirati seksualnu edukaciju odgovarajućim informacijama, na način prihvatljiv adolescentima, uz sagledavanje značajne uloge interneta u informisanosti o ovoj temi kod adolescenata.

Acta Medica Medianae 2019;58(3):40-48. zdravlje

KIjučne reči: srednjoškolci, seksualno ponašanje, kontracepcija, reproduktivno 